The Role of Social Capital in the Formation of Entrepreneurship Skills on Agricultural Farms

Kemalettin AĞIZAN ${ }^{\mathscr{2}}$, Zeki BAYRAMOĞLU2 ${ }^{2}$

Selçuk Üniversitesi Ziraat Fakültesi Tarım Ekonomisi Bölümü Konya

${ }^{1}$ https://orcid.org/0000-0002-2340-2614, ${ }^{2}$ https://orcid.org/0000-0003-3258-3848

$\triangle$ : agizankemalettin@gmail.com

\begin{abstract}
Social capital is important in the formation of entrepreneurship, consisting of cultural values of society, confidence, norm and social relations. Accordingly, the main objective of this study was to examine the relationship between the social capital and the entrepreneurial skills of agricultural farms. In accordance with this purpose, the stratified random sampling method was used for sampling. A survey was conducted with 76 agricultural farms determined according to this method. The reliability and validity tests of the scales used in the study were carried out, and the social capital and entrepreneurship skills were divided into dimensions, respectively. A significant relationship was determined by correlation analysis to calculate the degree of binary changes between the dimensions. In order to determine whether there is a significant relationship between social capital and entrepreneurship skills, which is the main aim of the study, structural equality model is established. According to the results of the analysis, it was determined that there was a significant and positive relationship between social capital dimensions and entrepreneurship skills.
\end{abstract}

Research Article
$\begin{array}{ll}\text { Article History } \\ \text { Received } \quad 07.01 .2020 \\ \text { Accepted } \quad: 20.02 .2020\end{array}$

Keywords

Agriculture farms

Entrepreneurship skills

Path analysis

Social capital

\title{
Tarım İşletmelerinde Girişimci Becerilerinin Oluşmasında Sosyal Sermayenin Rolü
}

\section{ÖZET}

Sosyal sermaye, toplumun kültürel değerlerinden, güven, norm ve sosyal ilişkilerinden oluşarak girişimciliğin oluşturulmasında önemli bir rol oynar. Buna göre bu çalışmanın temel amacı sosyal sermayenin ve tarım işletmecilerinin girişimcilik becerileri arasındaki ilişkiyi incelemektir. Bu amaç doğrultusunda popülasyondan örnek çekmede tabakalı tesadüfi örnekleme yöntemi kullanılmıştır. Bu yönteme göre belirlenen 76 tarım işletmecisi ile anket yapılmıştır. Araştırmada kullanılan ölçeklerin güvenilirlik ve geçerlilik testleri yapılmış olup, sosyal sermaye 5 boyutlu bir yapıya ve girişimcilik becerileri ise 3 boyutlu bir yapıya sahip olduğu belirlenmiştir. Boyutlar arasında ikili değişimlerin derecesini hesaplamak için yapılan korelasyon analiziyle boyutlar arasında anlamlı bir ilişki belirlenmiştir. Çalışmanın temel amacı olan sosyal sermaye ile girişimcilik becerileri arasında anlamlı bir ilişki olup olmadığını belirlemek için ise yapısal eşitlik model kurulmuştur. Yapılan analiz sonucunda elde edilen bulgulara göre sosyal sermaye boyutları ile girişimcilik becerileri arasında anlamlı ve pozitif yönlü bir ilişkinin var olduğu belirlenmiştir.

\section{Araştırma Makalesi}

Makale Tarihçesi
Geliş Tarihi $\quad: 07.01 .2020$

Anahtar Kelimeler

Tarım İşletmeleri

Girişimcilik Becerileri

Path analizi

Sosyal Sermaye

To Cite : Ağızan K, Bayramoğlu Z 2020. The Role of Social Capital in the Formation of Entrepreneurship Skills on Agricultural Farms. KSU J. Agric Nat 23 (3): 678-686. DOI: 10.18016/ksutarimdoga.vi.671706.

\section{INTRODUCTION}

Social capital in agricultural entrepreneurship is the degree of creating social relationships and confidence. The social capital of agricultural farms includes relationships like the subjective norm, cultural values, confidence, initiative and volunteerism, which are at the base of the social relationships of the actors in the sector. All these relationships facilitate collaboration, information sharing and joint action among farms. This task of social capital will facilitate the activities of entrepreneurs and provide productive results like physical capital. With the increase in the social capital levels of the entrepreneur active in the rural area, 
production costs will be reduced, and the social problems will be overcome by the increasing confidence factor. Also, social capital is an important resource for entrepreneurs with low income, low education levels, and with limited access to physical and economic capital.

Therefore, the agriculture sector has a high dependence to climatic factors and needs external financial resources (Dbeys and Engindeniz, 2011). Therefore, when there are no risk on management strategies such as credit or insurance, high social capital strength became an important risk management strategy of entrepreneurs against these shocks. In this way, the productivity of entrepreneurs in the agricultural sector could be increased and new applications and innovations could be adopted. While this relationship between social capital and entrepreneurs showing similar characteristics for all sectors, the population in the agricultural sector is more homogenous than the other sectors. Having stronger individual relationships and family ties in the agricultural sector leads to the formation of robust social capital. Therefore, the main objective of the study was to examine the relationship between entrepreneurship and social capital in the agricultural sector.

Social capital studies are usually related to social sciences, and studies including the relationship between social capital and poverty, the role of social capital in economic development, the relationship between civil society and social capital, the impact of social capital on farms success, sharing knowledge, the determinants of social capital, the relationship between social capital and efficiency, and the measurement of social capital (Karagül and Dündar, 2006; Özdemir, 2008; Eşki, 2009; Kovacı et al., 2009; Göksel et al., 2010; Duman and Alacahan, 2011; Ardahan, 2012). Studies that examine the relationship between entrepreneurship and social capital are limited (Yetim, 2002; Akyazı, 2014; Tarhan et al., 2016). The studies about social capital in rural areas is usually related to the desire to live in rural areas (Keleş et al., 2015), the formation (Keleş, 2014) and the elements of social capital (Çekiç and Tuba, 2009). This study becomes very important since the studies about analyzing the relationship between the entrepreneur in the agricultural sector and social capital in sectorial dimension is inadequate (Sharp and Smith, 2003). The main purpose of this study was to determine the relationship between entrepreneurial skills and social capital. In this context, structural equation model has been established in order to determine the relationship between the entrepreneurship skills and the social capital of the agricultural farms in Çumra, Konya. With the help of the results obtained with this model, suggestions were given to policymakers and practitioners to establish new alternative development models in agricultural farms.

\section{MATERIAL and METHOD}

Primary and secondary data were used within the scope of the study and primary data were obtained through a survey. Being suitable for the purpose of the research, Çumra district of Konya with high entrepreneurial characteristics of agricultural farms, was chosen as the study location(Bayramoğlu et al., 2019). The stratified random sampling method was used in order to get the variation coefficient more than $75 \%$ in the sampling from the population and to evaluate the farms as homogenous. By using 90\% confidence interval and 5\% error, a total of 76 sample agricultural farms were interviewed.

In the scope of the research, 76 agricultural farms were surveyed in order to determine the relationship between social capital and entrepreneurial skills. While conducting the survey, 2 different scales were prepared under the headings of social capital and entrepreneurship skills. The scales were prepared according to the 5 th scale and are determined as $1=$ very low, $2=$ low, $3=$ medium, $4=$ high, $5=$ very high in the classification of scales. In addition, more than one study was used while preparing the social capital scale (Onyx and Bullen, 2000; Paldam and Svendsen, 2000; Hudson and Chapman, 2002), and the scale created by Ağıan (2018) was used to determine entrepreneurial skills. The items in the original scale of the social capital scale are given in Table 1 and items of entrepreneurship skills are given in Table 2. It was excluded from factor analysis since it did not match any items with social capital scale items or because it was not possible to explain matched items with theory. All items related to entrepreneurship skills were used in the study.

Some tests are required to determine the consistency and suitability of the prepared scales. In the literature, Cronbach's Alpha value is used to test the reliability of the survey containing the Likert type question scales. Kaiser-Mayer-Olkin (KMO) test is used to determine whether the scales were suitable for factor analysis and factor analysis was performed because the result obtained was greater than 0.5. After factor analysis, correlation analysis was performed to determine the relationship between the dimensions, and structural equality model is established to det1ermine the degree of relationship between each dimension. The structural equation model prepared with the help of SPSS AMOS program which is a very useful model for displaying multiple dependent variables and independent variables in the same graph.

\section{RESULTS and DISCUSSION}

In order to understand the entrepreneurship skills and social capitals of agricultural enterprises, the socioeconomic characteristics of enterprises should be 
Table 1. Social Capital Scale

Cizelge 1. Sosyal Sermaye Ölçĕgi

Most people in Konya are honest and trustworthy.

I go to another village or city to visit my relatives.

I think that helping others is to help yourself in the long term.

In this city, people must always be blind, or others will usurp their rights.

I eliminate the garbage or mess that I see around me.

I think I can get along with people from different cultures living around me.

They consider the welfare of their families mainly to the people around me, they are not concerned with the welfare of their neighborhood or region.

I think the state's agricultural support will increase income in our village.

I am aware of the agricultural and rural development policies implemented by the state.

I take someone in to my house who is stuck in a difficult position.

When I compare with the other villages, I think the village I live in is more reliable.

If I have a problem, someone will help me absolutely.

If you drop your wallet, someone will see it and bring it back to you.

I have at least three close friends and it gives me peace to talk with them.

I like to live with people who have different lifestyles.

I follow the news every day.

I visit the district directorate of agriculture

I listen to the radio once a week.

I use the internet several times a week.

I do intercity call at least twice a week.

I feel safe walking out in the evenings.

When I disagree with any neighbor, I have a conciliative attitude.

When I need information on any subject, I know where and how I can find it.

Do you give financial aid to a member of the cooperative whose work getting worse?

Do you give financial aid your neighbor/friend who is not a member of the cooperative whose work getting worse.

Do you give financial aid your friend who is a member of a different cooperative whose work getting worse.

I feel as part of where I live.

There have been times when I argued with my neighbors.

People in Konya are always more reliable than those in other cities.

Most of the people in Konya help when you need help.

In order to make an investment in our village, all the villagers come together and share ideas.

I am satisfied with the health services provided to our village.

I took part in an organization for our village

When you make a new investment, we can get the support of official institutions.

I think I am a decision maker in the local organization's participation committee.

Source: (Onyx and Bullen, 2000; Paldam and Svendsen, 2000; Hudson and Chapman, 2002)

Table 2. Entrepreneurship Skills Scale

Cizelge 2. Girişimcilik Becerileri Ölçeği

Adaptation to Change

Being Innovative

Establish an Effective Management Model

Financial Competence Sufficiency

Having Technical Equipment

Managing Information and Communication Systems

Planning and Creating A Target

Providing Motivation, Coordination and Organization

To Be Able to Communicate Effectively

To Be Able to Establish Good Human Relations

To be able to make bargain and being a negotiator

To Be Able to Make Effective Decisions

To Be Able to Set Up and Manage A Team

To be aware from Effective Writing

To be determined

To be disciplined

To Be Tolerant

To Be Understanding

To Develop Effective Social Relations

To Have Professional Competence

Tolerance and Acceptance of Results

Source: Ağızan (2018) 
examined. In this context, the average age of the managers in the enterprises has been determined as 46 , the rate of primary school graduates is $59.21 \%$, secondary school graduate is $15.79 \%$, high school graduate is $21.05 \%$, higher school $2.63 \%$ and university graduate ratio is $1.32 \%$. In addition, it is known that the level of education increases in terms of business scales. As a matter of fact, education level is the most important determining factor in the formation of social capital, and there is a linear relationship between the increase of education level and social capital and entrepreneurship (Kaya, 2011). Another socio-economic feature is social security. It is determined that agricultural enterprises have a green card rate of $69.74 \%$ and this rate increases according to the scale of the enterprise.

\section{Confidence and Validity Analyze of Scales}

Within the scope of the study, we used an entrepreneurship skill scale which is prepared by Ağızan (2018). The Cronbach Alphas Alpha value of this scale is 0.894 . Since this value is greater than 0.8 , it can be said that the survey has high reliability. Among the prepared scales, social capital scale by (Onyx and Bullen, 2000; Paldam and Svendsen, 2000; Hudson and Chapman, 2002) is used. Cronbach's Alpha value, which shows the reliability of the scale, differs between 76-94\% in studies (Kaya, 2011; Turgut, 2013). The Cronbach's Alpha value of the social capital scale used in the study was calculated as 0.863 . Since this value is greater than 0.8 , it can be said that the survey has high reliability.

While the Cronbach's Alpha value is only a test of the reliability of the scale, there are different methods for determining the structure validity. Among these methods, factor analysis method is one of the most frequently used methods in the literature. However, before the factor analysis, Kaiser-Mayer-Olkin (KMO) test is performed to determine whether the scale was suitable for factor analysis. As a result of the KaiserMayer-Olkin (KMO) test, the value of social capital scale is 0.829 and the value of entrepreneurial skills is 0.949 , it is determined that it is suitable for factor analysis on both scales (Table 3).

Table 3. KMO and Bartlett's test results for entrepreneurship skills and social capital

Cizelge 3-Girisimcilik becerisine ve sosyal sermayeye ait KMO ve Bartlett's test sonuçları (Turkish)

\begin{tabular}{|c|c|c|c|}
\hline \multicolumn{2}{|l|}{ KMO and Bartlett's Test } & Social Capital & Entrepreneurship Skills \\
\hline \multicolumn{2}{|c|}{ Kaiser-Mayer-Olkin (KMO) Value for Sampling Capability } & 0.829 & 0.949 \\
\hline & Chi-Square Value & 476.569 & 756.459 \\
\hline \multirow[t]{2}{*}{ Bartlett's Sphericity Test Results } & Degree of Freedom (df) & 65 & 118 \\
\hline & Sig. & 0.000 & 0.000 \\
\hline
\end{tabular}

Table 4. Dimensions of entrepreneurship skills

Cizelge 4- Girişimcilik beceri boyutları (Turkish)

\begin{tabular}{|c|c|c|c|c|c|c|}
\hline & & Mean & $\begin{array}{l}\text { Std. } \\
\text { Deviation }\end{array}$ & $\begin{array}{l}\text { Factor } \\
\text { Loads }\end{array}$ & $\begin{array}{l}\text { Variance } \\
\text { Ratio }\end{array}$ & $\begin{array}{l}\text { Reliability } \\
\text { Coefficients } \\
\end{array}$ \\
\hline & Being Innovative & 4.394 & .880 & 0.956 & \multirow{7}{*}{39.56} & \multirow{7}{*}{$\begin{array}{l}\text { Cronbach's } \\
\text { Alpha } \\
(0.932)\end{array}$} \\
\hline$\stackrel{0}{=}$ & Adaptation to Change & 4.500 & .808 & 0.942 & & \\
\hline 牙 & To be determined & 4.105 & .932 & 0.923 & & \\
\hline$\tilde{2}$ & To be disciplined & 3.539 & .900 & 0.910 & & \\
\hline$\overbrace{0}^{\tilde{0}}$ & To Be Understanding & 3.921 & .875 & 0.856 & & \\
\hline$\underbrace{0}_{0}$ & To Be Tolerant & 3.828 & .985 & 0.795 & & \\
\hline 2 & Planning and Creating A Target & 3.434 & 1.235 & 0.748 & & \\
\hline & To Be Able to Make Effective Decisions & 1.697 & .783 & 0.895 & \multirow{7}{*}{23.42} & \multirow{7}{*}{$\begin{array}{l}\text { Cronbach's } \\
\text { Alpha } \\
(0.876)\end{array}$} \\
\hline & To Be Able to Establish Good Human Relations & 4.210 & .837 & 0.874 & & \\
\hline $\overrightarrow{0}$ & Establish an Effective Management Model & 3.684 & .926 & 0.865 & & \\
\hline घี & Financial Competence Sufficiency & 3.394 & .895 & 0.824 & & \\
\hline$\underset{\infty}{\infty}$ & Tolerance and Acceptance of Results & 3.947 & 1.005 & 0.756 & & \\
\hline డ్రి & To be able to make bargain and being a negotiator & 4.000 & .966 & 0.732 & & \\
\hline$\sum^{\infty}$ & Providing Motivation, Coordination and Organization & 3.842 & .909 & 0.721 & & \\
\hline & To be aware from Effective Writing & 1.697 & .783 & 0.954 & \multirow{7}{*}{19.25} & \multirow{7}{*}{$\begin{array}{l}\text { Cronbach's } \\
\text { Alpha } \\
(0.816)\end{array}$} \\
\hline 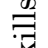 & To Have Professional Competence & 4.210 & .837 & 0.926 & & \\
\hline$\sqrt{2}$ & Having Technical Equipment & 4.105 & .932 & 0.894 & & \\
\hline శ్ర & Managing Information and Communication Systems & 3.539 & .900 & 0.846 & & \\
\hline$\stackrel{\bullet}{\Xi}$ & To Be Able to Communicate Effectively & 3.921 & .875 & 0.821 & & \\
\hline 공 & To Develop Effective Social Relations & 3.828 & .985 & 0.789 & & \\
\hline$\rightleftarrows$ & To Be Able to Set Up and Manage A Team & 3.434 & 1.236 & 0.763 & & \\
\hline & & & & & 82.23 & 0.894 \\
\hline
\end{tabular}

Overall, entrepreneurship skills were reduced to three subgroups, personal, managerial and technical skills (Table 4). As a result of factor analysis, factor loads, variance ratios and reliability coefficients are given in the table according to factor dimensions. Accordingly, the power to explain of the three dimensions, which 
was determined, was calculated as $82.23 \%$. The reliability coefficient of the scale was 0.894 . Social capital was analyzed with a total of 5 sub-factor dimensions. Accordingly, these dimensions to explain social capital was determined as $85.40 \%$. The reliability coefficient of the scale was calculated as 0.863 (Table 5).

Table 5. Social capital dimensions

Cizelge 5. Sosyal sermaye boyutları

\begin{tabular}{|c|c|c|c|c|c|c|}
\hline & & Mean & Std. Dev. & $\begin{array}{l}\text { Factor } \\
\text { Loads }\end{array}$ & $\begin{array}{l}\text { Variance } \\
\text { Ratio }\end{array}$ & $\begin{array}{l}\text { Reliability } \\
\text { Coefficients }\end{array}$ \\
\hline & I eliminate the garbage or mess that I see around me. & 4.632 & .629 & 0.945 & \multirow{6}{*}{24.29} & \multirow{6}{*}{$\begin{array}{l}\text { Cronbach's } \\
\text { Alpha }(0.906)\end{array}$} \\
\hline & $\begin{array}{l}\text { I take someone in to my house who is stuck in a } \\
\text { difficult position. }\end{array}$ & 4.382 & .672 & 0.923 & & \\
\hline हृत्र & Most of the people in Konya help when you need help. & 4.289 & .669 & 0.910 & & \\
\hline Z & If I have a problem, someone will help me absolutely. & 4.171 & .822 & 0.876 & & \\
\hline.$\stackrel{D}{0}$ & $\begin{array}{l}\text { When I disagree with any neighbor, I have a } \\
\text { conciliative attitude. }\end{array}$ & 4.263 & .998 & 0.862 & & \\
\hline$\frac{\mathscr{2}}{\stackrel{2}{2}}$ & $\begin{array}{l}\text { I think that helping others is to help yourself in the } \\
\text { long term. }\end{array}$ & 3.132 & 1.349 & 0.803 & & \\
\hline & Most people in Konya are honest and trustworthy. & 4.092 & 1.022 & 0.887 & \multirow{4}{*}{20.18} & \multirow{4}{*}{$\begin{array}{l}\text { Cronbach's } \\
\text { Alpha }(0.876)\end{array}$} \\
\hline$\underset{\Xi}{\circlearrowright}$ & $\begin{array}{l}\text { People in Konya are always more reliable than those } \\
\text { in other cities. }\end{array}$ & 4.105 & .775 & 0.840 & & \\
\hline$\stackrel{\overrightarrow{0}}{0}$ & I feel safe walking out in the evenings. & 4.434 & .805 & 0.784 & & \\
\hline 己ृ & $\begin{array}{l}\text { When I compare with the other villages, I think the } \\
\text { village I live in is more reliable. }\end{array}$ & 4.158 & .938 & 0.765 & & \\
\hline$\underline{y}$ & $\begin{array}{l}\text { I think I can get along with people from different } \\
\text { cultures living around me. }\end{array}$ & 4.184 & .962 & 0.912 & \multirow{6}{*}{18.35} & \multirow{6}{*}{$\begin{array}{l}\text { Cronbach's } \\
\text { Alpha }(0.846)\end{array}$} \\
\hline$\sum_{0}^{0}$ & $\begin{array}{l}\text { I have at least three close friends and it gives me peace } \\
\text { to talk with them. }\end{array}$ & 3.934 & 1.192 & 0.846 & & \\
\hline Z & I like to live with people who have different lifestyles. & 3.842 & .784 & 0.821 & & \\
\hline$\cdot \frac{\pi}{0}$ & I visit the district directorate of agriculture & 3.895 & 1.206 & 0.765 & & \\
\hline ஜ & I do intercity call at least twice a week. & 3.961 & 1.088 & 0.721 & & \\
\hline & I took part in an organization for our village & 3.855 & .919 & 0.935 & & \\
\hline & $\begin{array}{l}\text { In order to make an investment in our village, all the } \\
\text { villagers come together and share ideas. }\end{array}$ & 3.816 & .760 & 0.914 & \multirow{3}{*}{12.23} & \multirow{3}{*}{$\begin{array}{l}\text { Cronbach's } \\
\text { Alpha }(0.813)\end{array}$} \\
\hline 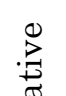 & $\begin{array}{l}\text { I am aware of the agricultural and rural development } \\
\text { policies implemented by the state. }\end{array}$ & 3.776 & 1.065 & 0.896 & & \\
\hline . & $\begin{array}{l}\text { When you make a new investment, we can get the } \\
\text { support of official institutions. }\end{array}$ & 3.803 & 1.020 & 0.847 & & \\
\hline & $\begin{array}{l}\text { Do you give financial aid to a member of the } \\
\text { cooperative whose work getting worse? }\end{array}$ & 3.789 & .984 & 0.889 & \multirow{3}{*}{10.36} & \multirow{3}{*}{$\begin{array}{l}\text { Cronbach's } \\
\text { Alpha }(0.756)\end{array}$} \\
\hline 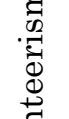 & $\begin{array}{l}\text { Do you give financial aid your friend who is a member } \\
\text { of a different cooperative whose work getting worse. } \\
\text { Do you give financial aid your neighbor/friend who is }\end{array}$ & 3.855 & .904 & 0.846 & & \\
\hline$\underset{\Xi}{\Xi}$ & $\begin{array}{l}\text { not a member of the cooperative whose work getting } \\
\text { worse. }\end{array}$ & 3.632 & .921 & 0.789 & & \\
\hline Tote & al Variance Explained & & & & 85.40 & 0.863 \\
\hline
\end{tabular}

\section{Correlation Analysis}

Correlation analysis was performed in order to determine the relationship between factor groups obtained from factor analysis. Correlation analysis measures the degree of interchange between dimensions and how the effect of independent variables on the dependent variables. The upper limit of the standard error of the coefficients in both correlation and structural equation model was taken as $20 \%$ within the scope of the research.

The results of the correlation analysis determined a significant and linear relationship between personal skills and subjective norms, confidence, initiative and volunteerism. There was no significant relationship between personal skills and social networking (Table 6). There was a significant relationship between the management skills, which were another dimension of entrepreneurship, between subjective norm, confidence, social network and volunteer dimensions. There was no significant relationship between management skills and initiative. There was a significant relationship between the management 
skills, which was the last dimension of entrepreneurship skills, between subjective norm and confidence dimensions. A meaningful and linear relationship between technical skills and initiative and volunteerism was determined (Table 6).

Table 6. The correlation between the dimensions of entrepreneurship skills and the dimensions of social capital Cizelge 6. Girişimcilik becerilerinin boyutları ile sosyal sermaye boyutları arasındaki korelasyon (Turkish)

\begin{tabular}{|c|c|c|c|c|c|c|c|c|c|}
\hline \multicolumn{10}{|c|}{ Correlation } \\
\hline \multirow[b]{2}{*}{ PS } & & KB & YB & TB & ÖN & GVN & SA & GRS & GNL \\
\hline & $\begin{array}{l}\text { Pearson Correlation } \\
\text { Sig. }\end{array}$ & 1 & & & & & & & \\
\hline \multirow{2}{*}{ MS } & Pearson Correlation & $.917^{* *}$ & 1 & & & & & & \\
\hline & Sig. & 0.000 & & & & & & & \\
\hline \multirow{2}{*}{ TS } & Pearson Correlation & $.764^{* *}$ & $.544^{* *}$ & 1 & & & & & \\
\hline & Sig. & 0.000 & 0.000 & & & & & & \\
\hline \multirow{2}{*}{$\mathrm{SN}$} & Pearson Correlation & $.657^{* *}$ & $.534^{* *}$ & 0.689 & 1 & & & & \\
\hline & Sig. & 0.000 & 0.000 & 0.650 & & & & & \\
\hline \multirow{2}{*}{ TRS } & Pearson Correlation & $.726^{* *}$ & $.523^{* *}$ & 0.619 & $.780^{* *}$ & 1 & & & \\
\hline & Sig. & 0.000 & 0.000 & 0.550 & 0.000 & & & & \\
\hline \multirow{2}{*}{$\mathrm{SN}$} & Pearson Correlation & 0.480 & $.708^{* *}$ & $.669^{* *}$ & $.665^{* *}$ & $.858^{* *}$ & 1 & & \\
\hline & Sig. & 0.560 & 0.000 & 0.000 & 0.000 & 0.000 & & & \\
\hline \multirow{2}{*}{ INI } & Pearson Correlation & $.499^{*}$ & 0.215 & $.664^{*}$ & $.602^{* *}$ & $.887^{* *}$ & $.617^{* *}$ & 1 & \\
\hline & Sig. & 0.012 & 0.650 & 0.038 & 0.000 & 0.000 & 0.000 & & \\
\hline \multirow{2}{*}{ VLT } & Pearson Correlation & $0.643^{* *}$ & $0.009^{*}$ & $0.533^{*}$ & $0.587^{*}$ & $0.135^{*}$ & $0.099^{*}$ & $.640^{* *}$ & 1 \\
\hline & Sig & 0.000 & 0.050 & 0.025 & 0.012 & 0.038 & 0.046 & 0.000 & \\
\hline
\end{tabular}

**. Correlation is significant at the 0.01 level (2-tailed).

*. Correlation is significant at the 0.05 level (2-tailed).

\section{Structural Equality Model (SEM)}

The structural equation model (SEM) facilitates the determination of the direction and reason of the relationship between multiple dependent and independent variables. For this reason, more than one relationship was revealed together with SEM analysis. Factor scores of factor groups were used in SEM, which allowed 15 different hypotheses to be presented in the same graph (Figure 1).

The degree of freedom was the most important value among those of the established structural equation model. Since the degree of freedom is 2 within the scope of the study, the model is over saturated. Another important point to consider is the importance level. This value is required to be greater than 0.05 .

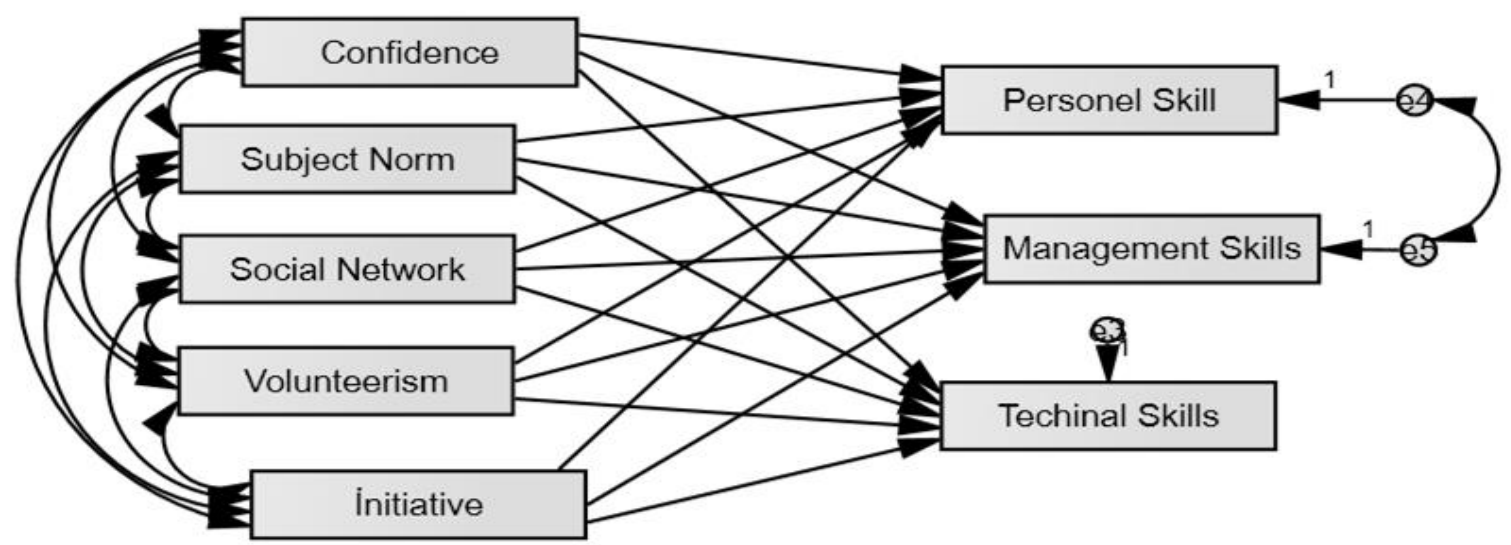

Figure 1. Structural equality model for the relationship between social capital and entrepreneurship skills Şekil 1. Sosyal sermaye ile girişimcilik becerileri arasındaki ilişkiye ait yapısal eşitlik modeli (Turkish)

If the value is greater than 0.05 it means that that the model fits the data and it is calculated as 0.076 . In addition, some fit indices are used to determine whether the results of the analysis are appropriate for the theory. The values of normal, acceptable and analysis results of these fit indices are shown in Table
7 .

According to the table, the values obtained as a result of structural equation model were at the limit of acceptable values and regression results should be interpreted.

The regression weights interpreted in the structural 
equation model because each of the scales in the model are the same time and measurement methods. The estimation and significance levels of the model results are given in Table 8. In the structural equation model, it is interpreted that if a unit change occurs in the independent variable how it affects the dependent variable. In this context, a unit change in the subjective norm variable will increase the personal skill by 0.244 units. Similarly, a one-unit increase of the subjective norm would lead to an increase of 0.242 in management skills, and no relationship was found between the subjective norm and technical skill. In the same way, a unit increase of subjective norm will result in an increase of 0.242 in management skills, and there is no relationship between subjective norm and technical skill.

Table 7. Structural equality model fit indices

Cizelge 7. Yapısal eşitlik modeli uyum endeksleri (Turkish)

\begin{tabular}{llll}
\hline İndex & Normal Value & Acceptable Value & Analysis Value \\
\hline $\mathrm{X}^{2}$ "p" Değeri & $\mathrm{p}>0.05$ & - & 0.082 \\
$\mathrm{X}^{2 / \mathrm{sd}}$ & $<2$ & $<5$ & 2.579 \\
GFI & $>0.95$ & $>0.90$ & 0.984 \\
AGFI & $>0.95$ & $>0.90$ & 0.906 \\
CFI & $>0.95$ & $>0.90$ & 0.943 \\
RMSEA & $<0.05$ & $<0.08$ & 0.080 \\
RMR & $<0.05$ & $<0.08$ & 0.030 \\
\hline
\end{tabular}

Source: (Kalayc1, 2010)

Table 8. Regression weights for relationship between social capital dimensions and entrepreneurship skills Cizelge 8. Sosyal sermaye boyutları ile girişimcilik becerileri arasındaki ilişkiye yönelik regresyon ă̆ırlıkları

\begin{tabular}{llllllll}
\hline $\begin{array}{l}\text { Dependent } \\
\text { Variable }\end{array}$ & $\begin{array}{l}\text { Relationship } \\
\text { Direction }\end{array}$ & $\begin{array}{l}\text { Independent } \\
\text { Variable }\end{array}$ & \multirow{2}{*}{ Estimate } & $\begin{array}{l}\text { Standard } \\
\text { Error }\end{array}$ & \multirow{2}{*}{ C.R. } & Sig. & Hypothesis \\
\hline PS & $<---$ & SN & 0.244 & 0.106 & -2.305 & 0.021 & Accepted \\
MS & $<--$ & SN & 0.242 & 0.104 & -2.322 & 0.020 & Accepted \\
TS & $<--$ & SN & 0.091 & 0.112 & 0.811 & 0.417 & Rejected \\
PS & $<--$ & TRS & 0.207 & 0.110 & 1.880 & 0.060 & Accepted \\
MS & $<--$ & TRS & 0.255 & 0.109 & 2.349 & 0.019 & Accepted \\
TS & $<--$ & TRS & -0.079 & 0.117 & -0.669 & 0.504 & Rejected \\
PS & $<--$ & SN & 0.001 & 0.103 & 0.013 & 0.990 & Rejected \\
MS & $<--$ & SN & 0.262 & 0.102 & 2.573 & 0.010 & Accepted \\
TS & $<--$ & SN & 0.211 & 0.110 & 1.918 & 0.055 & Accepted \\
PS & $<--$ & INI & 0.265 & 0.111 & 2.378 & 0.017 & Accepted \\
MS & $<--$ & INI & -0.083 & 0.110 & -0.757 & 0.449 & Rejected \\
TS & $<--$ & INI & 0.206 & 0.119 & 1.741 & 0.082 & Accepted \\
PS & $<--$ & VLT & 0.206 & 0.103 & -1.988 & 0.047 & Accepted \\
MS & $<--$ & VLT & 0.165 & 0.112 & -1.477 & 0.140 & Accepted \\
TS & $<--$ & VLT & 0.147 & 0.105 & -1.398 & 0.162 & Accepted \\
\hline
\end{tabular}

Confidence, which is another component of social capital, has a significant relationship between personal skill and management skills, and no signify

cant relationship has been found between technical skills. In fact, confidence develops through personal relationships and management skills. Another component of social capital is the social network. The social network explains its relationship with the society in which the entrepreneur is involved. Within the scope of the study, a statistically significant relationship between management and technical skill of social network variable was determined and no relationship between personal skills was determined.

In many studies related with the social capital, the components of social capital are divided into three groups. Within the scope of this study, the entrepreneurship characteristics and volunteering tendencies of entrepreneurs are considered as the dimensions of social capital (Narayan and Cassidy, 2001; Eşki, 2009). In this context, initiative is evaluated as the new organizations in which individuals participate and their tendencies towards them. There is a significant relationship between initiative and personal skill and technical skill, and there is no statistical relationship between management skills. The last component of social capital is volunteerism. As a matter of fact, if the level of volunteerism is low, social capital will decrease, and if high, social capital will increase and social and economic inequalities will decrease (Silva and Edwards, 2004). In this context, it is determined whether there is a relationship between volunteerism and entrepreneurial skills as a component of social capital. Accordingly, a significant and positive relationship has been determined between volunteerism, personal, management and technical skills. 


\section{CONCLUSIONS}

In Turkey the agricultural sector between 1980-1990, the concept of social capital, which emerged as an integral dimension of confidence and social networks, aims to create synergies between individuals. With this synergy created, the confidence, norm and social relations of the society could be improved. Therefore, social capital and entrepreneurship are important components of social development, growth and prosperity in the agricultural sector.

Thus, when the relationships between the dimensions of social capital and entrepreneurship skills are evaluated, it is determined that if entrepreneurship skills increase as a result social capital increases in general. There is a significant relationship between confidence and entrepreneurship among the social capital dimensions, which arises from the fact that agricultural entrepreneurs exhibit a communal culture. In addition, the agricultural farms adopt a sense of trust in the moral and religious rules that they adopt, as well as changing the structure of subjective norms and exhibiting solidarity. In agricultural farms, because their cultural values and family relations are stronger and they are more sensitive to social events, the social capital assets of these entrepreneurs are stronger. Therefore, it is necessary to adopt policies that will increase the social capital existence in the agricultural sector. This situation will increase entrepreneurship and increase value added at macro level. Therefore, an inventory study should be conducted for the existence of social capital in agricultural farms and a social capital index should be established. With this index, the social capital assets owned by the agricultural farms should be expressed in monetary terms and farms must compare each other.

\section{Statement of Conflict of Interest}

Authors have declared no conflict of interest.

\section{Author's Contributions}

The contribution of the authors is equal.

\section{REFERANCES}

Ağızan K 2018. Tarım İşletmelerinde Girişimciliği Etkileyen Faktörlerin Analizi. Selçuk Üniversitesi Fen Bilimleri Enstitüsü Tarım Ekonomisi Anabilim Dalı, Yüksek Lisans Tezi, 278 sy.

Akyazı TE 2014. Girişimcilik Sürecinde Sosyal Sermaye ve Sosyal Ağlar ile İç Girişimcilik Arasındaki İlişki Üzerine Bir Araştırma. Aksaray Üniversitesi Sosyal Bilimler Enstitüsü İşletme Anabilim Dalı Yönetim ve Organizasyon Bilim Dalı, Yükseklisans Tezi, 162 sy.

Ardahan F 2012. Sosyal Sermaye Ölçeği Geçerlilik, Güvenirlilik Çalışması. Uluslararası İnsan
Bilimleri Dergisi 9(2): 773-789.

Çekiç İ, Tuba SÇ 2009. Kırsal Kalkınma Açısından Sosyal Sermayenin Öğeleri: Şanlıurfa-Hilvan Örneği. Yıldız Teknik Üniversitesi Fen Bilimleri Enstitüsü Şehir ve Bölge Planlama Anabilim Dalı Şehir Planlama Bilim Dalı, Yükseklisans Tezi, 197 sy.

Dbeys AD, Engindeniz S 2011. Tarımsal Üretimde Şirketleşme Üzerine Üretici Görüş ve Tutumları: Izmir Örneği. Ege Üniversitesi Ziraat Fakültesi Dergisi 48(3): 191-201.

Duman B, Alacahan O 2011. Sosyal Sermaye/Güven Boyutunda Etniklik. Gaziantep University Journal of Social Sciences 10(1): 181-208.

Eşki H 2009. Sosyal Sermaye-Önemi, Üretimi ve Ölçümü-Üzerine Bir Alan Araştırması. Selçuk Üniversitesi Sosyal Bilimler Enstitüsü İşletme Anabilim Dalı İşletme Bilim Dalı, Yüksek Lisans Tezi, 278 sy.

Göksel A, Aydıntan B, Bingöl D 2010. Örgütlerde Bilgi Paylaşim Davranişi: Sosyal Sermaye Boyutundan Bir Bakış. Ankara Üniversitesi SBF Dergisi 65(4): 87-109.

Kalaycı Ş 2010. SPSS Uygulamalı Çok Değişkenli İstatistik Teknikleri. Asil Yayın Dağıtım Ankara, Türkiye, 426 sy.

Karagül M, Dündar S 2006. Sosyal Sermaye ve Belirleyicileri Üzerine Ampirik Bir Çalışma. Akdeniz İIBBF Dergisi 6(12): 61-78.

Kaya Y 2011. Sosyal Sermaye Düzeyinin Belirlenmesi ve Sosyal Sermaye Düzeyini Etkileyen Faktörlerin Analizi: Gönüllü Teşekküller Bağlamında Kayseri Örneği. Dumlupinar Üniversitesi Sosyal Bilimleri Enstitüsü İktisat Anabilim Dalı, Yükseklisans Tezi, 143 sy.

Keleş Ş 2014. Kırsal Alanda Sosyal Sermayenin Oluşumu Üzerine Bir Araştırma: Erzurum İli Örneği. Atatürk Üniversitesi Fen Bilimleri Enstitüsü Tarım Ekonomisi Anabilim Dalı, Doktora Tezi, 106 sy.

Keleş Ş, Dilmaç ÖGM, Dikmen A 2015. Sosyal Sermayenin Kırsal Alanda Yaşama İsteği Üzerinde Etkisi: Erzurum Kirsal Alaninda Bir Araştirma. The International New Issues In Social Sciences 1(1): 91-116.

Kovacı S, Belke M, Koç A 2009. İktisadi Kalkınmaya Yeni Yaklaşımlar: Sosyal Sermayenin ve Kurumlarin Artan Rolü. International Davraz Congress on Social and Economic Issues Shaping the World's Future: New Global Dialogue, 24-27.

Narayan D, Cassidy MF 2001. A Dimensional Approach to Measuring Social Capital: Development and Validation of A Social Capital İnventory. Current sociology 49 (2): 59-102.

Oğuz C, Karakayacı Z 2017. Tarım Ekonomisinde Araştırma ve Örnekleme Metodolojisi. Konya, Atlas Akademi, 183 sy. 
Onyx J, Bullen P 2000. Measuring Social Capital in Five Communities. The Journal of Applied Behavioral Science 36 (1): 23-42.

Özdemir AA 2008. Çalışanların İş Tatminlerinin Arttırılmasında Örgütsel Sosyal Sermaye Yeni Bir Belirleyici Olabilir mi?. Yönetim Bilimleri Dergisi 6(1): 77-89.

Sharp JS, Smith MB 2003. Social Capital And Farming at the Rural-Urban İnterface: The İmportance of Nonfarmer and Farmer Relations. Agricultural systems 76(3): 913-927.

Silva EB, Edwards R 2004. Operationalizing Bourdieu on Capitals: a Discussion on 'the Construction of the Object'. ESRC Research Methods Programme Working Paper 8.
Tarhan O,Selcen S, Peker İ 2016. Girişimcilik Başarı Faktörü Olarak Sosyal Sermaye Kriterlerinin Analitik Hiyerarşi Süreci (AHS) ile Ağırlıklandırılması ve Bir Ölçek Önerisi. Ekonomik ve Sosyal Araştırmalar Dergisi 12(1): 177-194.

Turgut E 2013. Sosyal Sermaye ve Bilgi Paylaşımı Davranışının Yenilikçilik İklimine Etkisi. Gazi Üniversitesi Sosyal Bilimler Enstitüsü İşletme Anabilim Dalı İşletme Bilim Dalı, 216 sy.

Yamane T 1967. Elementary sampling theory. Prentice Hall 1st Edition, 405 pp.

Yetim N 2002. Sosyal Sermaye Olarak Kadın Girişimciler: Mersin Örneği. Ege Akademik Bakış Dergisi 2(2): 79-92. 